J. Amer. Soc. Hort. Sci. 115(1):89-93. 1990.

\title{
Nitrogen Fertilization Influences the Physiology of Apple Leaves Subjected to European Red Mite Feeding
}

\author{
Richard J. Campbell ${ }^{1}$ and Richard P. Marini ${ }^{2}$ \\ Department of Horticulture, Virginia Polytechnic Institute and State University, \\ Blacksburg, VA 24061
}

Additional index words. Malus domestica, Panonychus ulmi, net photosynthesis, chlorophyll, transpiration, plant nutrition

\begin{abstract}
The interaction of $\mathrm{N}$ fertilization and European red mite (ERM) [Panonychus ulmi (Koch)] feeding on the physiology of greenhouse-grown 'Imperial Delicious' apple (Malus domestica Borkh.) leaves was evaluated. Visual damage was noticeable with 75 mite days (MD) and was consistently greatest on the low-N leaves. Net photosynthesis (Pn) was decreased by mite feeding in all $\mathrm{N}$ treatments. However, with equal MD, the high- $\mathrm{N}$ treatment retained higher Pn than the low- or medium-N treatments. Transpiration, dark respiration, leaf $\mathrm{N}$, and total chlorophyll increased with $\mathbf{N}$ and were reduced by mite feeding. Mite feeding increased dark transpiration at all $\mathbf{N}$ levels. Relative water content was unaffected by $\mathbf{N}$ and was reduced by mite feeding. Specific leaf weight increased with $\mathbf{N}$ and $\mathrm{MD}$.
\end{abstract}

The European red mite (ERM) is an important foliage-feeding pest on apple. ERM remove cellular contents by direct penetration of mesophyll cells with piercing-sucking mouthparts (Avery and Briggs, 1968). Mite feeding leads to cellular collapse and results in the characteristic bronzing of the foliage. Mite

Received for publication 2 Mar. 1989. The cost of publishing this paper was defrayed in part by the payment of page charges. Under postal regulations, this paper therefore must be hereby marked advertisement solely to indicate this fact.

'Graduate student.

${ }^{2}$ Associate Professor. feeding decreases photosynthesis (Avery, 1964; Hall and Ferree, 1975), transpiration (Ferree and Hall, 1981), leaf chlorophyll content (Chapman et al., 1952), and leaf N (Klopfenstein and Holdsworth, 1978). The balance of growth-regulating substances in plum is also altered by mite feeding (Avery and Lacey, 1968).

Plant response to mite feeding is influenced by environmental conditions (Storms, 1971) and plant vigor (Zwick et al., 1976). In the greenhouse, summer-grown bean plants were more tolerant than winter-grown plants to twospotted spider mite (TSM) (Tetranychus urticae Koch) feeding (Storms, 1971). Briggs and Avery (1968) measured reduced shoot length and dry weight in 
apple and plum following ERM feeding, but ERM feeding had no effect on the growth of peach (McClernan and Marini, 1986) or apple trees (Beers and Hull, 1987). Zwick et al. (1976) attributed the lack of a mite effect on the growth and cropping of 'Newtown' and 'Golden Delicious' apple trees to the extreme vigor of the trees studied.

If vigorous trees indeed tolerate mite feeding better than others, action thresholds for mite control might be modified, and mite control costs reduced. This study was designed to evaluate the influence of various $\mathrm{N}$ treatments on the physiology of 'Delicious' leaves subjected to ERM feeding.

\section{Materials and Methods}

'Imperial Delicious'/MM. 111 trees were planted in 3.7-liter containers on 13 Apr. 1988, and grown in a greenhouse under natural light. The medium consisted of equal parts by volume of peat, perlite, and vermiculite. Trees were headed $\approx 5 \mathrm{~cm}$ above the bud union at planting, and one vigorous shoot per plant was allowed to develop. Pests and mite predators were controlled according to standard spray recommendations. Micronutrients were applied at planting as a soluble trace element mix (W.R. Grace and Co., Allentown, Pa.) at $600 \mathrm{mg} \cdot \mathrm{liter}^{-1}$. In preliminary studies, $\mathrm{Mg}$ deficiency was observed; therefore, $\mathrm{MgSO}_{4}$, at $12.5 \mathrm{~g} \cdot \mathrm{liter}^{-1}$, was applied foliarly 4 weeks after planting.

Eighteen uniform trees, $\approx 45 \mathrm{~cm}$ tall, were chosen for the study. The experimental design was completely randomized with a factorial arrangement of three $\mathrm{N}$ levels and three mite levels. Each tree was randomly assigned either a low-, medium-, or high-N treatment to provide six trees per $\mathrm{N}$ treatment. Nitrogen treatments were supplied by adding $400 \mathrm{ml}$ of $\mathrm{NH}_{4} \mathrm{NO} 3$ solutions per plant at 0 (low), 150 (medium), or 300 (high) mg.liter ${ }^{-1}$. These solutions were applied weekly, for a total of 5 weeks beginning on 14 May. Therefore, each tree received 0, 20, or $40 \mathrm{mg} \mathrm{N} /$ tree per week, respectively. Phosphoric acid $\left(\mathrm{H}_{3} \mathrm{PO}_{4}\right)$ and $\mathrm{KCl}$ at 50 and $120 \mathrm{mg} \cdot$ liter $^{-1}$, respectively, were applied in the solutions with the $\mathrm{N}$ treatments.

On 1 June, three consecutive, fully expanded leaves per tree were randomly assigned either a control, low, or high mite treatment, providing six single-leaf replicates of each mite level per $\mathrm{N}$ treatment. In preliminary studies, we found that mite feeding on a single leaf had no measurable effect on adjacent leaves. Initial mite treatments consisted of 0,15 , and 20 mites per leaf. Mites were allowed to develop naturally, and all mobile stages were counted every 3 days. Control leaves were checked daily, and all mites removed. Mite days (MD) were calculated by averaging the number of mites counted on two consecutive dates, and multiplying by the number of 24-hr periods between the counts. Due to variation in leaf size between $\mathrm{N}$ treatments, mites were removed or added to keep mites per unit leaf area equal among $\mathrm{N}$ treatments.

At $0,5,12,21$, and 26 days after mite placement (DAMP), Pn of each leaf was measured in the laboratory with an Anarad model Ar-600 infrared gas analyzer. The chamber was a modification of the chamber described by Syvertsen and Smith (1983), but without a heat exchanger. Fans were used to negate boundary layer resistance. Light levels were maintained at 1050 $\mu \mathrm{mol} \cdot \mathrm{s}^{-1} \cdot \mathrm{m}^{-2}$ with four $500 \mathrm{r} / 3 \mathrm{FL}$ lamps (Westinghouse). Air flow rate into the chamber was $0.05 \mathrm{liter} \cdot \mathrm{s}^{-1}$ Air in the chamber was at $28 \pm 1 \mathrm{C}$ and relative humidity was $60 \% \pm 5 \%$. Transpiration (Tr) was measured simultaneously with Pn using a General Eastern model 1100 dew point hygrometer. Dark respiration $(\mathrm{Rd})$ and dark transpiration (Trd) were measured 26
DAMP with the same system after the trees had been in darkness for $2 \mathrm{hr}$ before measurement. Each leaf was rated for visual damage of mite feeding before each Pn measurement. Ratings were on a scale of 1 to 8 , where $1=$ no damage and $8=$ severe bronzing.

On 28 June (26 DAMP), leaves were harvested, weighed, and their area was measured with a LI-COR (LI-3000) portable area meter. Two leaf disks $\left(1.2 \mathrm{~cm}^{2}\right.$ total $)$ were sampled from each side of the midrib, and total chlorophyll content (TCHL) was determined by acetone extraction following the method of Arnon (1949), as modified by Marini (1986). The leaves were dried at $60 \mathrm{C}$ for $72 \mathrm{hr}$, and dry weights were recorded. Leaf $\mathrm{N}$ content (LFN) was determined by modified Kjeldahl analysis as described by Bremner and Breitenbeck (1983). Relative water
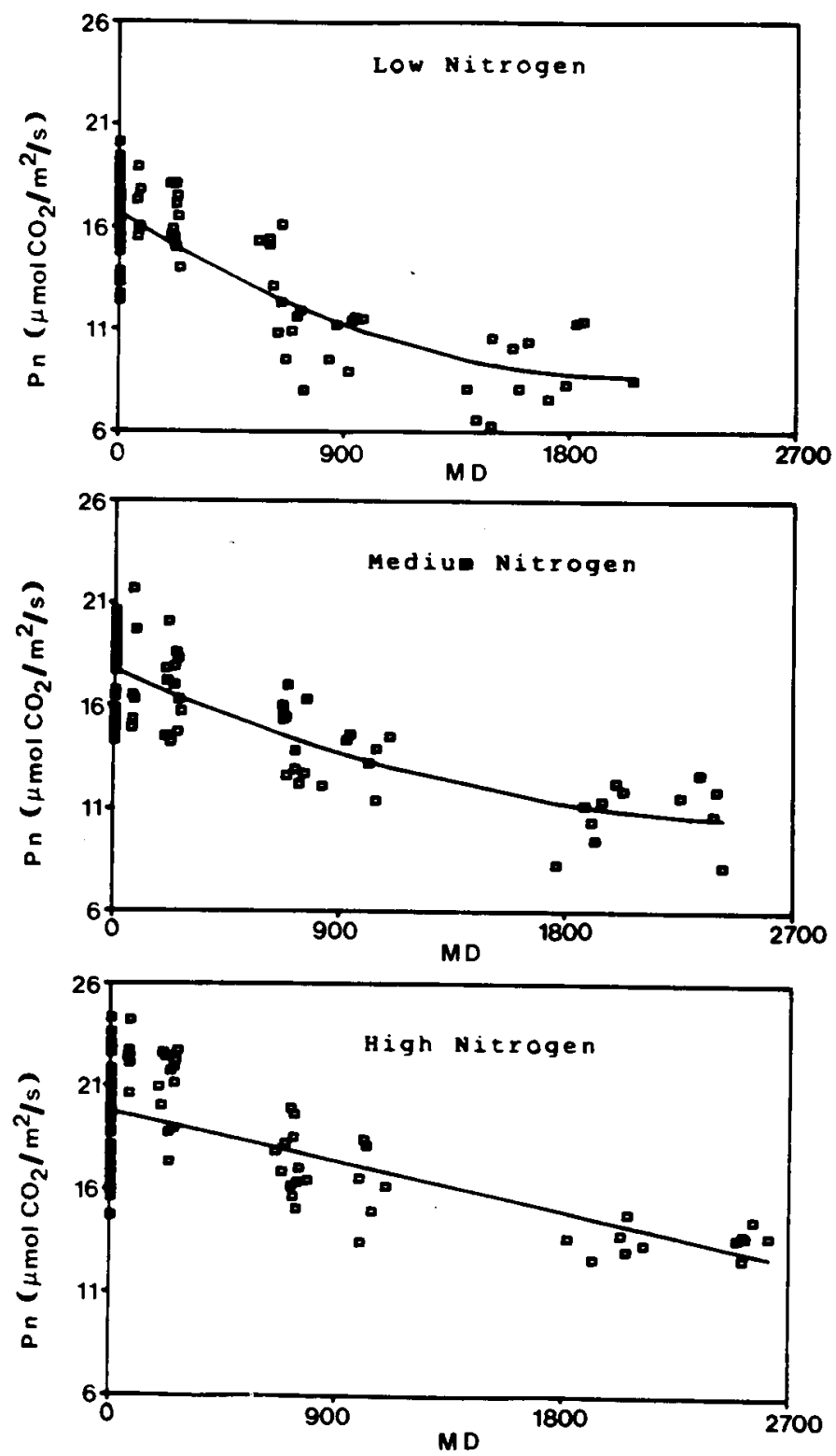

Fig. 1. Relationships between net photosynthesis $(\mathrm{Pn})$ and cumulative mite days per leaf (MD) for 'Imperial Delicious' apple leaves grown at three N levels. Low $\mathrm{N}: \mathrm{Pn}=16.7-0.008 \mathrm{MD}+1.9 \times 10^{-6}$ $\mathrm{MD}^{2}, R^{2}=0.68$. Medium N: $\mathrm{Pn}=17.7-0.005 \mathrm{MD}+1.0 \times$ $10^{-6} \mathrm{MD}^{2}, R^{2}=0.62$. High $\mathrm{N}: \mathrm{Pn}=19.7-0.003 \mathrm{MD}, R^{2}=$ 0.44 . 
Table 1. Multiple regression equations of net photosynthesis $(\mathrm{Pn})$ on days after mite placement (DAMP) and mite days (MD) for 'Imperial Delicious' apple trees grown at three N levels.

\begin{tabular}{ccc}
\hline \hline $\begin{array}{l}\text { Nitrogen level } \\
\text { (mg/tree per week) }\end{array}$ & Regression equation & \\
\hline 0 & $\mathrm{PN}=17.4-0.01 \mathrm{DAMP}^{2}-0.006 \mathrm{MD}+1.8 \times 10^{-6} \mathrm{MD}^{2}$ & 0.78 \\
20 & $\mathrm{PN}=18.8-0.14 \mathrm{DAMP}-0.003 \mathrm{MD}+5.0 \times 10^{-7} \mathrm{MD}^{2}$ & 0.76 \\
40 & $\mathrm{Pn}=20.0+0.19 \mathrm{DAMP}-0.01 \mathrm{DAMP}-0.002 \mathrm{MD}$ & 0.63 \\
\hline
\end{tabular}

${ }^{2}$ Regression equations were significant at $P<0.0001$.

content (RWC) of the leaf was calculated by subtracting dry weight from fresh weight and dividing by fresh weight.

Data were analyzed by analysis of variance. Depending on interactions, data were pooled and each treatment mean was tested against the control mean using Dunnett's procedure. Pn data were regressed on MD for each $\mathrm{N}$ treatment.

\section{Results and Discussion}

Cumulative mite days (MD) for the low and high mite treatments increased in a sigmoidal manner with time (data not presented). Control leaves accumulated $<50 \mathrm{MD}$ by the completion of the experiment. Expression of mite population density on an area basis (MD/ $\mathrm{cm}^{2}$ of leaf area) did not significantly improve the relationship between mite populations and the measured characteristics; therefore, all data analyses were performed on a MD per leaf basis. By day 26, the low and high populations equaled $\approx 980$ and $2200 \mathrm{MD}$, respectively.

$\mathrm{Pn}$ was reduced by mite feeding in all three $\mathrm{N}$ treatments. Since there was a significant mite $\times \mathrm{N}$ interaction, $\mathrm{Pn}$ was regressed on cumulative $\mathrm{MD}$ per leaf for each $\mathrm{N}$ level. A statistically unique model was found for each of the $\mathrm{N}$ treatments. Pn declined quadratically with increasing MD in the low- and medium-N treatments, and linearly in the high-N treatment (Fig. 1). MD accumulations $>2000$ reduced $\mathrm{Pn} 50 \%, 34 \%$, and $30 \%$ for the low-, medium-, and high-N treatments, respectively. Additional MD accumulations caused no further reduction in Pn in the low- and medium-N treatments. Following equal MD, high-N leaves maintained higher Pn rates than low-N leaves. This difference resulted from a higher initial Pn rate and less of a decline in Pn following mite damage.

Pn measurements were terminated 26 days after mite placement because low-N leaves were unable to support large mite populations, while populations continued to increase on the medium- and high-N leaves. Mite population differences were probably related to leaf $\mathrm{N}$ content because a positive relationship between leaf $\mathrm{N}$ content and mite populations has been reported in pecan (Jackson and Hunter, 1983).

Random fluctuations in Pn from one measurement date to another, and the gradual decline in Pn due to leaf aging, contributed to the variation in the data and resulted in relatively poor coefficients of determination (Fig. 1). To account for the variation due to leaf aging, multiple regression was performed with first- and second-order components of days after mite placement (as a measure of leaf age) and MD included as independent variables. This technique improved the models for all $\mathrm{N}$ treatments (Table 1 ).

Pn and ERM feeding were negatively related for apple and plum (Avery, 1964). Hall and Ferree (1975) measured a 26\% reduction in Pn following $135 \mathrm{MD}$ of TSM on container-grown 'Franklin' apple trees in the winter. Due to differences in experimental design and data analysis, direct comparison of our data with those of Hall and Ferree (1975) is difficult; however,
Table 2. Influence of $\mathbf{N}$ fertilization on European red mite damage ratings of 'Imperial Delicious' apple leaves.

\begin{tabular}{cccccc}
\hline \hline $\begin{array}{l}\text { Nitrogen level } \\
\text { (mg/tree per week) }\end{array}$ & 0 & 5 & 12 & 21 & 26 \\
\cline { 2 - 6 } & \multicolumn{5}{c}{ Rating } \\
0 & 1.0 & 2.4 & 3.3 & 4.6 & 4.9 \\
20 & 1.0 & $2.2^{*}$ & $3.0^{*}$ & $4.2^{*}$ & $4.6^{*}$ \\
40 & 1.0 & $2.0^{*}$ & $2.9^{*}$ & $3.9^{*}$ & $4.3^{*}$ \\
\hline
\end{tabular}

zTreatment means within column followed by an asterisk differed from the control by Dunnett's procedure, $P=0.05(\mathrm{n}=18)$.

vLeaves rated as $1=$ undamaged to $8=$ severely bronzed.

Table 3. Influence of European red mite population level on visual damage rating and transpiration ( $\mathrm{Tr}$ ) of 'Imperial Delicious' apple leaves at $0,5,12,21$, and 26 days after mite placement (DAMP). ${ }^{z}$

\begin{tabular}{|c|c|c|c|}
\hline Mite level & Mite days & Ratingy & $\begin{array}{c}\operatorname{Tr} \\
\left(\mathrm{mmol} \cdot \mathrm{s}^{-1} \cdot \mathrm{m}^{-2}\right) \\
\end{array}$ \\
\hline \multicolumn{4}{|c|}{$O D A M P$} \\
\hline Control & 0 & 1.0 & 3.6 \\
\hline Low & 0 & 1.0 & 3.7 \\
\hline High & 0 & 1.0 & 3.6 \\
\hline \multicolumn{4}{|c|}{$5 D A M P$} \\
\hline Control & 0 & 1.0 & 3.3 \\
\hline Low & $74^{*}$ & $2.0^{*}$ & 3.1 \\
\hline High & $244^{*}$ & $3.5^{*}$ & 3.0 \\
\hline \multicolumn{4}{|c|}{$12 D A M P$} \\
\hline Control & 0 & 1.0 & 2.6 \\
\hline Low & $215^{*}$ & $3.0^{*}$ & 2.4 \\
\hline High & $670^{*}$ & $5.2^{*}$ & 2.4 \\
\hline \multicolumn{4}{|c|}{$21 D A M P$} \\
\hline Control & 0 & 1.0 & 2.9 \\
\hline Low & $720^{*}$ & $4.7^{*}$ & 2.8 \\
\hline High & $1800^{*}$ & $6.9^{*}$ & $2.6^{*}$ \\
\hline \multicolumn{4}{|c|}{$26 D A M P$} \\
\hline Control & 0 & 1.0 & 2.6 \\
\hline Low & $980^{*}$ & $5.4^{*}$ & 2.6 \\
\hline High & $2200^{*}$ & $7.4^{*}$ & $2.3^{*}$ \\
\hline
\end{tabular}

${ }^{2}$ Treatment means within column and date followed by an asterisk differed from the control by Dunnett's procedure, $P=0.05(\mathrm{n}=18)$. y Leaves rated as $1=$ undamaged to $8=$ severely bronzed.

in our high-N treatment, $1800 \mathrm{MD}$ were required to achieve a $26 \%$ reduction in Pn. The two experiments differed in the mite species studied (TSM vs. ERM), apple cultivar, and the time of year the experiment was conducted (winter vs. spring). Youngman et al. (1986) found Tetranychus spp. (TSM) more damaging to almond Pn than Panonychus spp. (ERM).

Following pecan leaf scorch mite feeding, Pn was reduced in pecan seedlings fertilized with $\mathrm{N}$ at $200 \mathrm{mg} \cdot \mathrm{liter}^{-1}$, but seed- 
Table 4. Effect of $\mathrm{N}$ and European red mite treatments on dark respiration (Rd), dark transpiration (Trd), relative water content (RWC), specific leaf weight (SLW), total chlorophyll (TCHL), and leaf N (LFN) of 'Imperial Delicious' apple leaves. ${ }^{z}$

\begin{tabular}{|c|c|c|c|c|c|c|c|}
\hline \multirow[b]{2}{*}{ Treatment } & \multirow{2}{*}{$\underset{\left(\mu \mathrm{mol} \cdot \mathrm{s}^{-1} \cdot \mathrm{m}^{-2}\right)}{\mathrm{Rd}}$} & \multirow{2}{*}{$\begin{array}{c}\operatorname{Trd} \\
\left(\mathrm{mmol} \cdot \mathrm{s}^{-1} \cdot \mathrm{m}^{-2}\right)\end{array}$} & \multirow{2}{*}{$\begin{array}{c}\text { RWC } \\
(\%)\end{array}$} & \multirow{2}{*}{$\begin{array}{c}\mathrm{SLW} \\
\left(\mathrm{mg} \cdot \mathrm{cm}^{-2}\right)\end{array}$} & \multirow{2}{*}{$\begin{array}{c}\text { TCHL } \\
\left(\mu \mathrm{g} \cdot \mathrm{cm}^{-2}\right)\end{array}$} & \multicolumn{2}{|c|}{ LFN } \\
\hline & & & & & & $\mathrm{mg} \cdot \mathrm{cm}^{-2}$ & $\%$ \\
\hline \multicolumn{8}{|c|}{ Nitrogen levely } \\
\hline 0 & 0.25 & 0.10 & 67.7 & 5.6 & 21 & 0.10 & 1.8 \\
\hline 20 & 0.26 & 0.09 & 67.7 & $6.0^{*}$ & 23 & $0.13^{*}$ & $2.3^{*}$ \\
\hline 40 & $0.33^{*}$ & 0.12 & $68.1^{*}$ & $6.1^{*}$ & $30^{*}$ & $0.16^{*}$ & $2.7^{*}$ \\
\hline \multicolumn{8}{|l|}{ Mite days } \\
\hline 0 & 0.32 & 0.03 & 70.2 & 5.6 & 28 & 0.14 & 2.5 \\
\hline 980 & 0.30 & $0.13^{*}$ & $67.4^{*}$ & $6.0^{*}$ & $25^{*}$ & 0.13 & $2.2^{*}$ \\
\hline 2200 & $0.21^{*}$ & $0.15^{*}$ & $65.9 *$ & $6.1^{*}$ & $22^{*}$ & $0.12^{*}$ & $2.0^{*}$ \\
\hline
\end{tabular}

${ }^{2}$ Treatment means within column and variable followed by an asterisk differed from the control by Dunnett's procedure, $P=0.05(\mathrm{n}=18)$.

y Nitrogen level in $\mathrm{mg} / \mathrm{tree}$ per week.

lings receiving $\mathrm{N}$ at $600 \mathrm{mg} \cdot \mathrm{liter}^{-1}$ responded positively to mite feeding (Jackson and Hunter, 1983). The positive response to mite feeding was attributed to the removal of "excess" $\mathrm{N}$ by the mites. Direct comparison with our results is difficult due to the lack of methods presented by Jackson and Hunter; however, we found reductions in $\mathrm{Pn}$ at all three $\mathrm{N}$ levels (Fig. 1). The $600 \mathrm{mg} \mathrm{N} /$ liter level used by Jackson and Hunter (1983) resulted in leaf $\mathrm{N}$ concentrations of $4 \%$ or higher. These seedlings had low $\mathrm{Pn}$ rates $\left(<10 \mathrm{mg} \mathrm{CO} / \mathrm{dm}^{2}\right.$ per $\mathrm{hr}$ ) and reduced growth compared to the other $N$ treatments. Sparks and Baker (1975) found $\mathrm{N}$ toxicity symptoms in pecan seedlings with leaf $\mathrm{N}$ concentrations $>3.4 \%$.

Significant mite $\times \mathrm{N}$ and date $(\mathrm{DAMP}) \times \mathrm{N}$ interactions, were found for visual damage. It was first observed on the low$\mathrm{N}$ treatment, which had consistently higher ratings (more damage) throughout the experiment (Table 2). Visual damage ratings were positively related to mite level (Table 3). Visual damage, or bronzing, was detected 5 days after mite placement, corresponding to $75 \mathrm{MD}$. These results agree with the findings of Avery (1964) for ERM on apple. Hall and Ferree (1975), in contrast, did not observe visual damage at 540 MD with TSM on apple. Differences in feeding patterns between the mite species used in these experiments probably contributed to the conflicting results.

There was no $\mathrm{N} \times$ mite interaction for Tr. The high- $\mathrm{N}$ treatment averaged $10 \%$ to $15 \%$ higher $\mathrm{Tr}$ than the medium- and low-N treatments throughout the experiment. There was, however, a mite $\times$ date (DAMP) interaction. Tr was unaffected through 12 DAMP, but, on the final two measurement dates, Tr was reduced $10 \%$ and $12 \%$ by 1800 and $2200 \mathrm{MD}$, respectively (Table 3 ). Previous researchers measured an inconsistent mite effect on Tr of apple (Ferree and Hall, 1981), but these studies were conducted with TSM. We found no reports on the effect of ERM feeding on Tr of apple, but Youngman et al. (1986) measured decreased stomatal conductance in almond leaves with both ERM and TSM.

Since there were no interactions between $\mathrm{N}$ level and mite level for the remaining measured characteristics, main effect means for several variables are presented in Table 4 . Rd increased with $\mathrm{N}$, and decreased by $33 \%$ following $2200 \mathrm{MD}$ (Table 4). We are unaware of other studies relating mite feeding and $\mathrm{Rd}$. Reductions in Rd probably resulted from removal of cellular contents through mite feeding, including the enzymes and substrate necessary for $\mathrm{Rd}$.
Trd was unaffected by $\mathrm{N}$ treatment, but there was a 4- to 5fold increase in both the low and high mite treatments (Table 4). Leaf water potential was not measured, but relative water content (RWC) of the leaf was reduced $4 \%$ and $6 \%$ for the low and high mite treatments, respectively (Table 4). DeAngelis et al. (1982) measured increased water loss in the dark (Trd) on peppermint leaves infested with TSM. Mite-infested leaves lost up to 3.5 times more water than control leaves. The authors speculated that the loss of water in the darkness contributed to measured reductions in daytime Tr. Their data suggested that increased water loss was not a result of altered stomatal function in the dark. Instead, water loss was attributed to increased astomatal, or cuticular transpiration rate resulting from mechanical damage to the cuticle and disruption of epidermal cells. Histological studies demonstrated that ERM feeding did not damage epidermal cells (Avery and Briggs, 1968). Therefore, the increased Trd measured in our study was probably due to cuticular damage alone.

Specific leaf weight (SLW) was increased by both $\mathrm{N}$ and mite increases, but high and low levels of each had an equal effect (Table 4). The increased SLW associated with $\mathrm{N}$ was probably due to an influence on the leaf morphology (e.g., increase in cell number, cell size, or structural carbohydrates), or an increase in soluble sugars or starch. We have no explanation for the increased SLW following mite feeding, except as an increase in dry weight resulting from a wound response to mite feeding. Previous research demonstrated a highly significant relationship between SLW and Pn for apple leaves sampled from different regions of the tree canopy (Marini and Barden, 1981). However, following mite feeding, we found no correlation $(P>0.05)$ between SLW and Pn. The use of SLW to characterize previous light conditions or to estimate Pn potential maybe complicated by mite feeding.

TCHL was positively related to $\mathrm{N}$, but mite levels of 980 and $2200 \mathrm{MD}$ reduced it by $11 \%$ and $21 \%$, respectively, compared to the controls (Table 4). Chapman et al. (1952) measured 30\% reductions in TCHL of 'Delicious' leaves following ERM feeding. TCHL has often been used as the only measure of physiological damage in apple leaves due to mite feeding (Chapman et al., 1952; Zwick et al., 1976); however, we found poor relationships between TCHL and gas exchange characteristics of the leaf (data not shown). Expression of TCHL on $\mathrm{mg} \cdot \mathrm{g}^{-1}$ dry weight basis slightly improved the relationship with MD; 
however, poor relationships were still found with gas exchange characteristics of the mite-infested leaf.

LFN $\left(\mathrm{mg} \cdot \mathrm{cm}^{-2}\right)$ increased with $\mathrm{N}$ treatment, but was reduced $14 \%$ by $2200 \mathrm{MD}$ (Table 4 ). LFN (\%) followed the same trend, with a $20 \%$ reduction by $2200 \mathrm{MD}$ (Table 4 ). Reductions in LFN (\%) of up to $25 \%$ were reported for 'Delicious' apple leaves subjected to ERM feeding (Klopfenstein and Holdsworth, 1978). The recommendation in Virginia for a young, vigorous apple tree in the field is $\approx 2.4 \%$ to $2.6 \% \mathrm{~N}$. This level is comparable to our high-N treatment.

Mite feeding clearly has a negative influence on Pn of apple leaves, yet the mechanism of Pn reduction remains unclear. To better-explain reduced $\mathrm{Pn}$, a multiple regression was performed for Pn, with first- and second-order terms of LFN (area basis), RWC, Tr, and TCHL included as independent variables. The analysis indicated that the linear model including LFN and RWC was superior to all other variable combinations for predicting Pn $\left(R^{2}=0.61\right)$. TCHL and Tr did not add significant information to the model in the presence of LFN and RWC. Therefore, for our study, LFN and RWC were the best criteria for evaluation of Pn.

Our results indicate that the existing action threshold levels for ERM control in apple should be modified to account for leaf $\mathrm{N}$ concentration. Leaves at $2.7 \% \mathrm{~N}$ had a $40 \%$ greater Pn rate than comparable leaves at $1.8 \%$ following 2000 MD. Action thresholds vary according to location, time of year, mite : predator ratios, and environmental conditions; however, thresholds should be increased on high- $\mathrm{N}$ trees. These results are based on container-grown trees, and extrapolations to field conditions should be made with caution; however, preliminary studies indicate that field-grown trees may be more tolerant of mite feeding than greenhouse-grown trees.

\section{Literature Cited}

Arnon, D.I. 1949. Copper enzymes in isolated chloroplasts. Polyphenoloxidase in Beta vulgaris. Plant Physiol. 24:1-15.

Avery, D.J. 1964. Carbon dioxide exchange by plum and apple leaves damaged by fruit tree red spider mite. Rpt. E. Mailing Res. Sta., 1963. p. 94-97.

Avery, D.J. and J.B. Briggs. 1968. Damage to leaves caused by fruit tree red spider mite, Panonychus ulmi (Koch). J. Hort. Sci, 43:463473.

Avery, D.J. and H.J. Lacey. 1968. Changes in the growth-regulator content of plum infested with the fruit tree red spider mite Panonychus ulmi (Koch). J. Expt. Bot. 19:760-769.
Beers, E.H. and L.A. Hull. 1987. Effect of European red mite (Atari: Tetranychidae) injury on vegetative growth and flowering of four cultivars of apples. Environ. Entomol. 16:569-574.

Bremner, J.M. and G.A. Breitenbeck. 1983. A simple method for determination of ammonium in semimicro-Kjeldahl analysis of soils and plant materials using a block digester. Commun. Soil Sci. Plant Anal. 14:905-913.

Briggs, J.B. and D.J. Avery. 1968. Effects of infestation with fruit tree red spider mite, Panonychus ulmi (Koch), on the growth and cropping of young fruit trees. Ann. Applied Biol. 61:269-276.

Chapman, P.J., S.E. Lienk, and O.F. Curtis, Jr. 1952. Responses of apple trees to mite infestations: I. J. Econ. Entomol. 45:815-821.

DeAngelis, J.D., K.C. Larson, R.E. Berry, and G.W. Krantz. 1982. Effects of spider mite injury on transpiration and leaf water status in peppermint. Environ. Entomol. 11:975-978.

Ferree, D.C. and F.R. Hall. 1981. Influence of physical stress on photosynthesis and transpiration of apple leaves. J. Amer. Soc. Hort. Sci. 106:348-351.

Hall, F.R. and D.C. Ferree. 1975. Influence of twospotted spider mite populations on photosynthesis of apple leaves. J. Econ. Entomol. 68:517-520.

Jackson, P.R. and P.E. Hunter. 1983. Effects of nitrogen fertilizer level on development and populations of pecan leaf scorch mite (Acari:Tetranychidae). J. Econ. Entomol. 76:432-435.

Klopfenstein, W.G. and R.P. Holdsworth. 1978. The effects of European red mite feeding on the growth and yield of spur-type Delicious apple. Res. Circ. Ohio Agr. Res. Dev. Ctr. 239:35-37.

Marini, R.P. 1986. Do net gas exchange rates of green and red peach leaves differ? HortScience 21:118-120.

Marini, R.P. and J.A. Barden. 1981. Seasonal correlations of specific leaf weight to net photosynthesis and dark respiration of apple leaves. Photosyn. Res. 2:251-258.

McClernan, W.A. and R.P. Marini. 1986. European red mite on yield, fruit quality, and growth of peach trees. HortScience 21:244-246.

Sparks, D, and D.H. Baker. 1975. Growth and nutrient response of pecan seedlings, Carya illinoiensis, to nitrogen levels in sand culture. J. Amer. Soc. Hort. Sci. 100:392-399.

Storms, J.J.H. 1971. Some physiological effects of spider mite infestation on bean plants. Neth. J. Plant Pathol. 77:154-167.

Syvertsen, J.P. and M.L. Smith. 1983. An inexpensive leaf chamber for measuring net gas exchange. HortScience 18:700-701.

Youngman, R.R., V.P. Jones, S.C. Welter, and M.M Barnes. 1986. Comparison of feeding damage caused by four tetranychid mite species on gas-exchange rates of almond leaves. Environ. Entomol. 15:190-193.

Zwick, R.W., G.J. Fields, and W.M. Mellenthin. 1976. Effects of mite population density on 'Newtown' and 'Golden Delicious' apple tree performance. J. Amer. Soc. Hort. Sci. 101:123-125. 